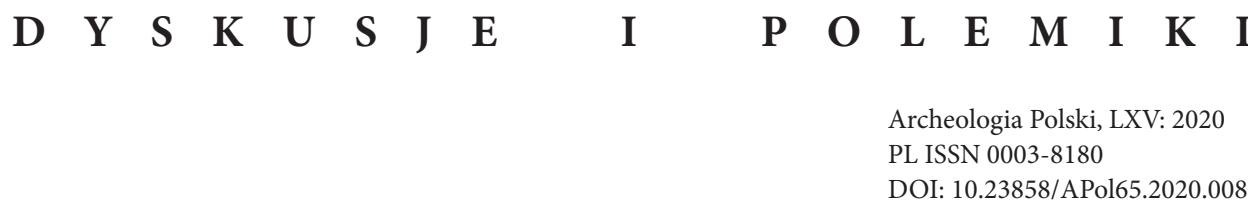

HALINA DOBRZAŃSKA ${ }^{a}$

\title{
W KWESTII UWARUNKOWAŃ ŚRODOWISKOWYCH WYTWÓRCZOŚCI CERAMIKI „ŚCIERALNEJ” W KULTURZE PRZEWORSKIEJ
}

\author{
NATURAL ENVIRONMENT FACTORS CONDITIONING THE \\ PRODUCTION OF “ABRADABLE” POTTERY IN PRZEWORSK CULTURE
}

\begin{abstract}
Abstrakt: W niniejszym artykule zwrócono uwagę na istotne znaczenie lokalnych cech środowiska paleogeograficznego w wytwórczości ceramiki. Ignorowanie faktów wynikających z jego analizy może prowadzić do błędów interpretacyjnych. Zagadnienie to omówiono na przykładzie ceramiki szarej, o powierzchniach ścieralnych, będącej odmianą szeroko rozpowszechnionej w Barbaricum (I-V w. n.e.) wykonanej na kole ceramiki barwy szarej o powierzchniach bez śladów ścieralności. Zwrócono uwagę na rolę użytych surowców, które przyczyniają się do powstawania efektu „ścieralności”. Podjęto dyskusję z koncepcją specjalnej technologii, która miała umożliwić produkcję dobrej jakości ceramiki z surowców o dużej zawartości kwarcu.
\end{abstract}

Słowa kluczowe: okres wpływów rzymskich, ceramika wykonana na kole, ceramika ścieralna, środowisko paleogeograficzne, technologia

\begin{abstract}
The author calls attention to the importance of local paleogeographic characteristics shaping pottery production. Ignoring facts resulting from a study of paleoenvironmental factors may lead to interpretative mistakes. The issue is discussed based on a variant of grey ware with abradable surfaces that derives from the smooth grey ware widespread in the Barbaricum ( $1^{\text {st }}$ to $5^{\text {th }}$ c. A.D.). The choice of raw materials for the production of this variant is instrumental in obtaining the "abradable" effect. The author questions the idea of a special technology for producing quality ceramics from raw material with abundant quartz.
\end{abstract}

Keywords: Roman Influence period, wheel-made ceramics, abradable pottery, paleogeographic environment, technology

${ }^{a}$ Dr Halina Dobrzańska, Ośrodek Archeologii Gór i Wyżyn, Instytut Archeologii i Etnologii PAN, ul. Sławkowska 17, 31-016 Kraków, halinadob@yahoo.pl, ORCID iD: https://orcid.org/00000002-7831-227X. 
Jednym z głównych teoretycznych zagadnień, rozpatrywanych przez Deana Arnolda w pracy zatytuowanej Ceramic theory and cultural process, jest aspekt ekologiczny studiów nad ceramiką. Ponad trzydzieści lat temu autor ten bardzo mocno podkreślał, że relacje między technologią a środowiskiem (geograficznym) muszą być rozpoznane przed rozpoczęciem studiów nad związkami ceramiki z innymi subsystemami kultury. Umożliwi to wyjaśnienie powiązań ceramiki archeologicznej zarówno z paleośrodowiskiem jak i z kulturą (Arnold 1985, s. 12-19).

Przedmiotem przedstawionej poniżej dyskusji jest próba wyjaśnienia przyczyn powstawania ceramiki, która w literaturze archeologicznej określana jest jako „ścieralna”. Chodzi tu o naczynia wykonane na kole garncarskim. Charakteryzuje je bardzo duża różnorodność, której wyrazem jest „mączysta” w dotyku powierzchnia, niekiedy mniej lub bardziej „miękka”, którą w niektórych przypadkach można łatwo zarysować. Te cechy odróżniają je od ceramiki „nieścieralnej”, o powierzchni twardej, wyświecanej, należącej do kategorii naczyń gładkich. Obie kategorie należą do ceramiki szarej, wykonanej na kole garncarskim, wypalanej w piecach dwudzielnych o pionowym ciągu powietrza, zagłębionych w ziemi. Proces wypału naczyń prowadzony był $\mathrm{w}$ warunkach redukcyjnych, z ograniczonym dostępem powietrza. Badania eksperymentalne, przeprowadzone w Haarhausen (Turyngia), wskazują na niezbyt wysoką temperaturę jej wypalania, $700^{\circ} \mathrm{C} \pm 35^{\circ} \mathrm{C}$ (Dušek i in. 1986, s. 59-63), co znalazło potwierdzenie w rezultatach experymentalnych wypałów przeprowadzonych w Krakowie-Branicach (Goerlich i in. 2005, ryc. 1;2) oraz w wynikach badań laboratoryjnych (Dobrzańska i in. 2008, s. 244-245).

Ceramika szara, wykonana za pomocą koła garncarskiego, jest znana z obszarów środkowej i wschodniej Europy i datowana od okresu przedrzymskiego do wczesnej fazy wędrówek ludów. W zespołach archeologicznych fragmenty naczyń „ścieralnych” współwystępują często z ceramiką "nieścieralną”, jak ma to miejsce w przypadku stanowiska w Bessowie, woj. małopolskie, stan. 3 (por. Okoński [1999] 2000, s. 150). Wyjątkiem jest osada w Pakoszówce, woj. podkarpackie, stan. 26, gdzie w obiekcie mieszkalnym niemal wszystkie odkryte fragmenty należały do ceramiki szarej o powierzchniach miękkich, ścieralnych (Madyda-Legutko 1996, s. 73).

Obszarem najliczniejszego występowania ceramiki „ścieralnej” w Polsce jest strefa beskidzka. Pod względem dużej liczby stanowisk wyróżnia się obszar Pogórza Bukowskiego i jego pogranicza z Pogórzem Dynowskim, skąd znana jest, badana wykopaliskowo, osada w Pakoszówce, stan. 26. Ceramika szara, o powierzchniach miękkich, ścieralnych, odkrywana jest w osadach nad Sanem, na Pogórzu Jasielskim, na przedpolu Beskidu Niskiego. Jej obecność odnotowano także na terenie Sądecczyzny (Madyda-Legutko 1996, s. 73-74, zestawienie IV.1, mapa 5; Madyda-Legutko i in. 2004; Bulas i in. 2019, s. 75).

Ceramika „ścieralna” znana jest w strefie osadnictwa nad Rabą, gdzie licznie występuje wśród odpadów produkcyjnych z pieców garncarskich. W Bessowie, stan. 3 stanowiła ok. 41\%, w Strzelcach Małych, stan. 13 ponad 50\% odrzuconej ceramiki (Okoński [1999] 2000, s. 150; Kordecki, Okoński 1999).

Stanowiska archeologiczne $\mathrm{z}$ omawianą tu kategorią naczyń zostały odkryte na prawym brzegu Wisły, np. Krakowie-Bieżanowie, stan. 8, 15, Krakowie-Kurdwanowie, stan. 1, Stanisławicach, stan. 9, woj. małopolskie (Dobrzańska i in. 2004, przypis 1), a także na jej równinie zalewowej, w Krakowie-Przewozie, stan. 2 (Dobrzańska, Kalicki 2018, s. 120, przypis 1). Do wyjątków należy ceramika o powierzchniach ścieralnych, odkryta wśród odpadów produkcyjnych na stanowisku w Tropiszowie, woj. małopolskie, stan. 1, oddalonym o kilka $\mathrm{km}$ na północ od pasma osad z licznymi pracowniami garncarskimi, usytuowanymi w strefie skłonu lessowej terasy Wisły, gdzie, jak dotąd, nie zaobserwowano podobnych cech technologicznych ceramiki (Dobrzańska i in. 2004, s. 686; Dobrzańska 2015). Na północ od Krakowa, na obszarze Wyżyny Krakowsko-Wieluńskiej, ceramika ścieralna znana jest z osady w Modlnicy, stan. 5, woj. małopolskie (Dzięgielewska, Dzięgielewski 2015). Fragmenty naczyń o powierzchniach ścieralnych odkryto także w pracowniach garncarskich z Chabielic, woj. łódzkie, stan. 12, w dorzeczu Warty, na obszarze środkowej Polski (Siciński 2000). 
One of the chief theoretical issues discussed by Dean Arnold in his book Ceramic theory and cultural process is the ecological aspect of pottery studies. More than 30 years ago Arnold had argued for recognizing the relations between technology and the (geographical) environment before studying pottery in connection with other cultural subsystems. It would lead to understanding the relation between ceramics and the paleoenvironment on one hand and culture on the other (Arnold 1985, pp. 12-19).

The objective of the present discussion is to understand the causes behind the production of so-called "abradable" ceramics, as they are called in the archaeological literature. These are wheel-made ceramics characterized by a large variety, sharing a surface that is "mealy" surface to the touch, more or less "soft" occasionally and sometimes easily scratched. These characteristics differentiate these ceramics from the "unabradable" variant with hard and burnished surface, belonging to the smooth vessel category. Both variants are known in the case of wheel-made grey ware, fired in an up-draft kiln, vertical and double-chambered, that is built on a circular plan and sunk into the ground. The firing process took place in a reduction atmosphere with restricted air access. Experimental research by Haarhausen (Thuringia) points to a rather low firing temperature at $700^{\circ} \mathrm{C} \pm 35^{\circ} \mathrm{C}$ (Dušek et al. 1986, pp. 59-63), confirmed by the results of experimental firings conducted in Kraków-Branice (Goerlich et al. 2005, Figs 1;2) and the outcome of laboratory analyses (Dobrzańska et al. 2008, pp. 244-245).

The wheel-made grey ware is recorded from central and eastern Europe, from contexts dated from the pre-Roman to the early Migration Periods. In archaeological assemblages, fragments of "abradable" vessels occur together with regular pottery, a good case in point being presented by site 3 at Bessów in the Małopolskie voivodeship (see Okoński [1999] 2000, p. 150). The settlement at Pakoszówka (site 26) in the Podkarpackie voivodeship is exceptional in this respect with almost all of the sherds from a dwelling unit representing the soft, abradable form of ceramics (Madyda-Legutko 1996, p. 73).

The region of the Beskid mountains is where this kind of pottery is the most common. The area of Bukowskie Foothills and its border with Dynów Foothills are distinguished by the largest number of sites, including the archaeologically excavated site 26 at Pakoszówka. Grey ware with soft, abradable surfaces has been discovered in settlements on the San river located in the Jasło Foothills and on the outskirts of the Lower Beskid mountain range. Its presence has been noted in the Sącz region as well (Madyda-Legutko 1996, pp. 73-74, list IV.1, map 5; Madyda-Legutko et al. 2004; Bulas et al. 2019, p. 75). It is also known from the area on the Raba river, where it is abundant among the production waste from pottery kilns. At Bessów, site 3, it made up about $41 \%$, at Strzelce Małe, site 13 it was about 50\% of the rejected pottery (Okoński [1999] 2000, p. 150; Kordecki, Okoński 1999).

Archaeological sites with this vessel category were discovered on the right bank of the Vistula, e.g. Kraków-Bieżanów, sites 8 and 15, Kraków-Kurdwanów, site 1, Stanisławice, site 9, all in the Małopolskie voivodeship (Dobrzańska et al. 2004, note 1), and in its floodplain, that is, KrakówPrzewóz, site 2 (Dobrzańska, Kalicki 2018, p. 120, note 1). Pottery with abradable surfaces found in the production waste comes exceptionally from a site at Tropiszów in the Małopolskie voivodeship, located just a few kilometers north of a series of sites with numerous pottery kilns lying in the loess slope zone of the Vistula terrace, where, so far, no similar technological features of ceramics have been observed (Dobrzańska et al. 2004, p. 686; Dobrzańska 2015). North of Kraków, in the region of the Kraków-Wieluń Upland, abradable pottery was recorded at site 5 in Modlnica, Małopolskie voivodeship (Dzięgielewska, Dzięgielewski 2015). Sherds of pottery with abradable surfaces were discovered also at the pottery workshops in Chabielice, site 12, Łódzkie voivodeship, in the basin of the Warta river in central Poland (Siciński 2000).

South of Polish territory, ceramic material of this kind is sparsely represented in eastern Slovakia and more common among the cultures associated with the free Dacians (Vîrtișcoiu-Poienești) 
Na południe od ziem Polski podobne materiały ceramiczne nielicznie reprezentowane są we wschodniej Słowacji. Szerzej znane są także w kulturach łączonych z wolnymi Dakami (Vîrtişcoiu-Poieneşti) w dorzeczu Seretu i Prutu oraz z Geto-Dakami (Militari-Chilia) w Muntenii (Madyda-Legutko 1996, s. 76, 77). Na uwagę zasługuje liczny udział ceramiki ścieralnej wśród odpadów produkcyjnych z pieców garncarskich w Beregsurány, kom. Szabolcs-Szatmár-Bereg (III-IV w.) we wschodniej części Węgier (Dobrzańska i in. 2004, przypis 2).

Po raz pierwszy omawiana tu ceramika została wyróżniona i nazwana przez Renatę Madydę-Legutko, w materiałach z polskiej strefy beskidzkiej. Jednocześnie podjęto próbę jej interpretacji, wskazując na jej formy i specyficzną technologię, którą należy łączyć z obcymi ludności kultury przeworskiej tradycjami garncarskimi, a mianowicie z garncarstwem społeczności tzw. kręgu kultur dackich, z II-IV w., z obszarów Mołdawii i Muntenii (Madyda-Legutko 1996, s. 76-77). Kilka lat później, na podstawie odkryć omawianej tu ceramiki w strefie osadnictwa w dolnym biegu Raby, Jerzy Okoński sformułował określenie „zespół typu Pakoszówka-Bessów”. U podstaw tej koncepcji znalazło się przekonanie o podobieństwie materiałów z Bessowa do ceramiki kultury Daków, zarówno pod względem form, jak i zastosowanej technologii, której efektem jest ścieralność powierzchni naczyń (Kordecki, Okoński 1999, s. 212; Okoński [1999] 2000, s. 153 i n.). O ile ceramika z osad na stanowiskach 26 i 1 w Pakoszówce, koło Sanoka ma wyraźne analogie w kręgu kultur dackich młodszego okresu rzymskiego (Madyda-Legutko 2010, s. 28-30), co jest zrozumiałe ze względu na terytorialną bliskość tych ostatních, to formy naczyń z Bessowa i z innych stanowisk nad Rabą nawiązują do ceramiki wytwarzanej w nieodległych pracowniach, odkrytych na terasie Wisły (Dobrzańska 2015, s. 402, 403). Ceramika „ścieralna” nie może być także wyznacznikiem kulturowym, ponieważ jest efektem ograniczonego dostępu do dobrej jakości surowców. Poza tym odnotowywana jest w różnych obszarach Barbaricum i charakteryzuje ją bardzo różnorodna powierzchnia i różny stopień twardości czerepu. Także pod tym względem trudno jest znaleźć podobieństwa między materiałami z Pakoszówki i Bessowa (Dobrzańska 2015, s. 404). Pomimo wykazania braku zasadności odnośnie do wyróżniania „zespołu typu Pakoszówka-Bessów” pojęcie to w dalszym ciągu jest używane w literaturze (Okońska [2017] 2018; Okońska i in. 2018).

Wyniki badań laboratoryjnych próbek ceramiki „ścieralnej” z osady w Pakoszówce, woj. podkarpackie, stan. 26, oraz z pieca garncarskiego w Sanoku, woj. podkarpackie, stan. 54, wskazują na jej „wystarczające walory użytkowe, nie jest przesiąkliwa, natomiast specyficzny charakter powierzchni naczyń jest uwarunkowany rodzajem i sposobem przygotowania surowca użytego do ich wyrobu" co zostało uznane jako wynik oddziaływań z dackiego kręgu kulturowego (Madyda-Legutko i in. 2004, s. 695-696; Madyda-Legutko 2010, s. 28).

Nowe dane dla interpretacji omawianej tu kategorii ceramiki wniosły rezultaty analiz laboratoryjnych, które objęły zarówno fragmenty naczyń „ścieralnych”, jak i „nieścieralnych”. Wyniki szczegółowych specjalistycznych badań próbek naczyń o powierzchniach „ścieralnych”, pochodzących z Moszczenicy Wyżnej, woj. małopolskie, stan. A, oraz z pracowni garncarskich z Chabielic, woj. łódzkie, stan. 12, porównane zostały z wynikami badań ceramiki dobrze utwardzonej, o powierzchniach gładkich, pochodzącej z Chabielic, stan. 12, i z pracowni ceramicznych z Zofipola, woj. małopolskie, stan. 1. Rezultaty przeprowadzonych analiz wskazują na negatywne właściwości tych pierwszych, którymi są słaba wytrzymałość mechaniczna i niska twardość czerepu. Ich przyczyna tkwi w nieodpowiedniej jakości użytego surowca, o niskiej zawartości substancji ilastej (Dobrzańska i in. 2003; 2004, s. 686). Te dwie niekorzystne właściwości wykluczają umieszczanie ceramiki „ścieralnej” na jednym poziomie, pod względem jakości, z ceramiką o dobrze utwardzonej strukturze. Właściwości te, ograniczając nieco jej walory użytkowe, nie eliminują jej jednak jako produktu nadającego się do użytku (Dobrzańska 2015). Należy także podkreślić, że z obu omawianych tu kategorii mas garncarskich, dających po wypaleniu odmienne efekty, wykonywano naczynia o tych samych formach.

Przyczynę efektu „ścieralności”, dotyczącego ceramiki z pracowni w rejonie dolnej Raby, badano w kontekście wyników analizy środowiska geograficznego (Dobrzańska 2015). Złożyły 
in the basins of the Seret and Prut, and the Geto-Dacian tribes (Militari-Chilia) in Muntenia (Madyda-Legutko 1996, pp. 76, 77). Of interest is the abundance of abradable pottery among the production waste from the $3^{\text {rd }}-4^{\text {th }}$ centuries A.D. pottery kilns at Beregsurány, Szabolcs-SzatmárBereg district, eastern Hungary (Dobrzańska et al. 2004, note 2).

This particular variant of grey ware was first distinguished and described by Renata Madyda-Legutko in material from the Polish Beskid zone. Its interpretation at the time indicated its form and specific technology as a feature deriving from a pottery tradition unknown to the Przeworsk Culture population, that is, the pottery of communities from the $2^{\text {nd }}$ to $4^{\text {th }} \mathrm{C}$. A.D. Dacian cultural milieu in the regions of Moldavia and Muntenia (Madyda-Legutko 1996, pp. 76-77). A few years later, Jerzy Okoński introduced the term "Pakoszówka-Bessów type group" based on finds from the settlement zone on the lower Raba river course. His idea was rooted in the formal as well as technological resemblance of the material from the Bessów site to Dacian pottery, the abradable surface of these vessels being a consequence of this (Kordecki, Okoński 1999, p. 212; Okoński [1999] 2000, pp. 153ff.). Pottery from Pakoszówka, sites 26 and 1, near Sanok, has evident parallels in the milieu of the Dacian cultures of the younger Roman period (Madyda-Legutko 2010, pp. 28-30), which is understandable in view of the territorial nearness of the latter, but the forms of vessels from Bessów and other sites on the Raba river resemble more closely pottery produced in the nearby workshops discovered on the Vistula river terrace (Dobrzańska 2015, pp. 402, 403).

As a matter of fact, "abradable" pottery is not a cultural indicator, because it results from restricted access to quality resources. It is recorded in different parts of the Barbaricum and features a highly variegated surface and different degrees of body hardness. Even in these terms it is difficult to establish the similarities between the material from Pakoszówka and from Bessów (Dobrzańska 2015, p. 404). Despite being shown as unjustified, the concept of a "Pakoszówka-Bessów type group" continues to be used in the literature (Okońska [2017] 2018; Okońska et al. 2018).

Laboratory analyses of "abradable" pottery samples from the settlement at site 26 in Pakoszówka and a furnace at Sanok site 54, both Podkarpackie voivodeship, have demonstrated that the ceramics have "sufficient utilitarian characteristics, are non-permeable, while the specific nature of the pot surface is determined by the use and special preparation of the raw material used for production". This was considered as representing influences coming from the Dacian cultural milieu (Madyda-Legutko et al. 2004, pp. 695-696; Madyda-Legutko 2010, p. 28).

New data for the interpretation of this category of ceramics comes from laboratory analyses of both variants of this ware, the "abradable" as well as the "unabradable". The outcome of laboratory studies on samples with "abradable" surface from site A in Moszczenica Wyżna, Małopolskie voivodeship, and the pottery workshops from Chabielice site 12, Łódzkie voivodeship, were compared with the results for a well hardened pottery with smooth surfaces from the same Chabielice site and the workshops at Zofipole site 1, Małopolskie voivodeship. The study has indicated the negative properties of the former, namely, poor mechanical endurance and low body hardness, resulting from the use of inadequate raw material with low content of clay (Dobrzańska et al. 2003; 2004, p. 686). In consequence, the easily abradable pottery cannot be placed on par with ceramics characterized by a well-hardened structure as far as quality is concerned, but while these properties limit the usefulness of these pots, they do not eliminate them entirely from use (Dobrzańska 2015). One should note that vessels of the same form were made from both categories of fabrics giving such different effects after firing.

The "abradability" effect regarding the pottery from the workshops in the lower Raba region was examined within the context of a study of the geographical environment (Dobrzańska 2015). The latter encompassed detailed research on the evolution of Raba and Uszwica, two Carpathian tributaries of the Vistula, in the Vistulian and Holocene (Gębica 1995). Settlement 
się na nie rezultaty szczegółowych badań ewolucji karpackich dopływów Wisły, a mianowicie Raby i Uszwicy, w vistulianie i holocenie (Gębica 1995). Osadnictwo zajmuje stary, opuszczony w wyniku awulsji Raby jej pas meandrowy, czynny w eo- i mezoholocenie, wyniesiony około $1 \mathrm{~m}$ powyżej późnoglacjalnych równin aluwialnych rzeki roztokowej, pełniących w holocenie rolę basenów powodziowych (Gębica 1995; Dobrzańska, Kalicki 2015, s. 108 i nn.). W interpretacji wytwórczości ośrodka garncarskiego nad Rabą wykorzystano obserwacje dotyczące morfologii, geologii i hydrologii interesującego nas obszaru (Dobrzańska 2015). Zwrócono uwagę na niedostatek dobrej jakości surowców ceramicznych w rejonie ujawnionych pracowni. Chodzi tutaj o surowce, w których składzie granulometrycznym stwierdzono niską zawartość frakcji ilastej (Gębica 1995, ryc. 15; Dobrzańska, Kalicki 2015, ryc. 13; Dobrzańska 2015, ryc. 13). Ich użycie mogło dawać, po wypaleniu, efekt ścieralności, mogło być przyczyną zarówno słabszej wytrzymałości mechanicznej, jak i niższej twardości ceramiki w porównaniu z naczyniami o powierzchniach „nieścieralnych”. Istnieje duże prawdopodobieństwo, że omawiana tu ceramika łatwiej ulegała zniszczeniu, także w trakcie wypalania, co mogło powiększać liczbę odpadów produkcyjnych stwarzających złudzenie jej masowości (Dobrzańska, Kalicki 2015, s. 109-111; Dobrzańska 2015, s. 404-405). Obok materiału mniej plastycznego, którego użycie powodowało ścieralność wypalonych naczyń, w pracowniach nad Rabą wykorzystywano także surowiec o mniejszej zawartości frakcji pylastej, do których mogły należeć mułki ilaste i iły (Gębica 1995, ryc. 15; Dobrzańska, Kalicki 2015, ryc. 13). Umożliwiał on wytwarzanie ceramiki o powierzchniach „nieścieralnych”.

$\mathrm{W}$ ostatnich latach podjęto badania nad rozpoznaniem technologii ceramiki z Bessowa, stan. 3 . W tym celu wykonano analizy laboratoryjne 42 fragmentów pochodzących z pracowni garncarskiej, odkrytej na tym stanowisku oraz z rejonu położonego w jej pobliżu, zachowanego szczątkowo, pieca garncarskiego (Daszkiewicz i in. 2018; Okońska i in. 2018). Spośród 22000 odkrytych tam fragmentów naczyń 8576 ma powierzchnie ścieralne. W ogólnej liczbie fragmentów 57\% stanowi ceramika szara, wypalana w warunkach redukcyjnych, natomiast pozostałe $47 \%$ to ułamki naczyń barwy brązowej, pomarańczowej i żółtej, noszące ślady warunków utleniających (Daszkiewicz i in. 2018, s. 50 i in.; Okońska i in. 2018, s. 100 i in.). Zarówno miejsce odkrycia tej ceramiki, jak i jej charakter (wielobarwność) dowodzą, że mamy do czynienia z odpadami produkcyjnymi. Są to fragmenty naczyń, które nigdy nie były używane, zatem nie mogą stanowić podstawy do badań nad ich technologią. Dokonane na ich podstawie pomiary temperatury, które wahają się od $900-1000^{\circ} \mathrm{C}$ nie określają temperatury wypalania ceramiki, ale jej zniszczenia. Nie może być zatem mowy o konsolidacji struktury czerepu w związku z zastosowaniem wysokiej temperatury wypału, co miało charakteryzować ten szczególny proces technologiczny. Jest ona efektem lokalnych warunków, wskazujących przede wszystkim na niekorzystną cyrkulację powietrza na terenie równiny zalewowej Raby. Gwałtowny podmuch powietrza dostarczał tlen, który zmieniał atmosferę z redukcyjnej na utleniającą i podnosił temperaturę w piecu. Problemy garncarzy z cyrkulacją powietrza można prześledzić na przykładzie, wspomnianych poniżej, konstrukcji pieców z pobliskich Strzelc Małych, stan. 13.

Autorzy najnowszych analiz laboratoryjnych ceramiki łączonej z pracownią i piecem w Bessowie potwierdzili, przytoczoną wyżej, wcześniejszą sugestię dotyczącą przyczyny powstania ceramiki „ścieralnej”, wskazując na charakter użytego surowca jako na główną przyczynę powstania efektu ścieralności. Masa garncarska użyta do produkcji badanej ceramiki zawierała $50 \%$ kwarcu, 30\% illitu i 20\% kaolinitu (Daszkiewicz i in. 2018, s. 53).

Badacze stanowisk odkrytych nad dolną Rabą sugerują związek nietypowej formy pieca ze stanowiska produkcyjnego w Strzelcach Małych, stan. 13, z lokalną gliną (Kordecki, Okoński 1999, s. 190-197; Okońska [2017] 2018, s. 353). Uwaga ta dotyczy pieców 1 i 2 z tunelami powietrznymi, urządzeniem dotychczas nieznanym na obszarze Barbaricum, oraz pieców 3 i 4 , spośród których jeden został zniszczony przez usytuowany na nim drugi piec, w którego konstrukcji zmieniono orientację wlotu do kanału ogniowego, w stosunku do obiektu starszego (Kordecki, Okoński 1999, s. 197 nn.; Okoński [1999] 2000, s. 120 nn., ryc. 27). 
occupied the old meander belt of the Raba, which was active in the Eo- and Mezoholocene, and was abandoned in consequence of river avulsion. This belt was about a meter higher than the late glacial alluvial plain of the braided river acting as a floodplain in the Holocene (Gębica 1995; Dobrzańska, Kalicki 2015, pp. 108 ff.). Observations concerning the morphology, geology and hydrology of the region were taken into account in the study of the pottery production center on the Raba (Dobrzańska 2015). The shortage of good quality raw material in the area of the pottery workshops was noted, the raw material showing a low content of clay in the granulometric composition (Gębica 1995, Fig. 15; Dobrzańska, Kalicki 2015, Fig. 13; Dobrzańska 2015, Fig. 13). Their use resulted in the abradable effect after firing and could have also been the cause of poorer mechanical endurance and lower body hardness compared to pottery featuring a surface that was not abradable. It is also likely that this pottery was more easily destroyed during the firing process, thus inflating production waste numbers, which in turn gave an impression of a more widespread distribution of these products than was actually the case (Dobrzańska, Kalicki 2015, pp. 109-111; Dobrzańska 2015, pp. 404-405). Other raw material than the one which resulted in the abradability of fired pottery from the Raba workshops was a material with a lower dusty fraction, such as clayey silts and clay (Gębica 1995, Fig. 15; Dobrzańska, Kalicki 2015, Fig. 13). The latter material was used for making ceramics without abradable surfaces.

The technology of pottery-making at Bessów, site 3, was studied in recent years on a sample of 42 sherds coming from the pottery workshop discovered at the site and the nearby, fragmentarily preserved pottery kiln (Daszkiewicz et al. 2018; Okońska et al. 2018). Abradable surfaces were noted on 8576 of the 22,000 sherds recorded at the site. Of the total number of fragments, $57 \%$ were grey ware products fired in a reduction atmosphere; the remaining $47 \%$ are vessels of brown, orange and yellow color bearing evidence of oxidation firing (Daszkiewicz et al. 2018, pp. 50ff.; Okońska et al. 2018, pp. 100ff.). This multicolored nature of the sherds, as well as the place where they were discovered, suggest that we are dealing with production waste. These fragments represent vessels that were never used, therefore are not suitable for technological studies. The measurements of temperature made on these sherds, oscillating around $900-1000^{\circ} \mathrm{C}$, show the temperature of destruction, not firing. One cannot speak of consolidating body structure by the application of a high firing temperature, which was supposed to characterize this specific technological process. The nature of the firing process is due to local conditions indicating an unfavourable air circulation in the Raba floodplain. Sudden rushes of air supplied oxygen that changed the reduction atmosphere in the furnace into one of oxidation, raising the temperature inside the kiln. The potters' problems with air circulation may be traced in the manner in which the kilns from nearby Strzelce Małe, site 13, were constructed (see below).

The Bessów investigation has confirmed an earlier suggestion, already cited above, that the "abradable" effect observed on these ceramics is for the most part due to the nature of the raw material used in the making of this pottery. The fabric in this case consisted of $50 \%$ quartz, $30 \%$ illite and 20\% kaolinite (Daszkiewicz et al. 2018, p. 53).

The excavators of the sites on the lower Raba suggested that the atypical form of the kilns from the production site at Strzelce Małe (site 13) was determined by the local clay (Kordecki, Okoński 1999, pp. 190-197; Okońska [2017] 2018, p. 353). The kilns in question where installations 1 and 2 with air tunnels, a feature previously unknown in the Barbaricum, and 3 and 4, of which one was destroyed by another kiln located on top of it, in which the feeding hole of the fire tunnel was aligned differently than in the older kiln (Kordecki, Okoński 1999, p. 197ff.; Okoński [1999] 2000, pp. 120ff., Fig. 27). Concerning the results of the geographic environment analyzes of this region it is difficult to accept the idea of a connection between the kiln construction and the local clay. Additional features present in the kiln structure highlight the inventiveness 
Biorąc pod uwagę wyniki analizy środowiska geograficznego tego obszaru, sformułowany pogląd o związku budowy pieca z lokalną gliną, jest trudny do zaakceptowania. Dodatkowe elementy konstrukcji to inwencja garncarzy, którzy starali się zniwelować straty w produkcji naczyń spowodowane niekorzystną, zmienną cyrkulacją powietrza panującą na równinie zalewowej Raby. Dodatkowym utrudnieniem na tym obszarze był wysoki poziom wód gruntowych w okresach częstych, krótkotrwałych powodzi, będących rezultatem deterioracji klimatu w okresie rzymskim (Dobrzańska, Kalicki [2011] 2013). W konstrukcji pieców widzimy podjętą przez garncarzy próbę adaptacji tych obiektów do niekorzystnych warunków, jakie oferowało im lokalne środowisko geograficzne. Należy przy tym zwrócić uwagę na dużą wiedzę i umiejętności wytwórców w budowie pieców i znajomość zasad ich funkcjonowania oraz doświadczenie w zakresie technologii.

Wymienione utrudnienia w wytwórczości mogły przyczynić się do znacznego zwiększenia liczby odpadów produkcyjnych w pracowniach odkrytych w osadach nad Rabą. Na tych fragmentach ceramiki odnajdujemy zapis zmagań garncarzy, zarówno z dostępnym surowcem, jak i z niekorzystnymi warunkami środowiskowymi, o czym świadczy duży udział (47\%) zniszczonych fragmentów naczyń o cechach odpowiadających niezamierzonym, utleniającym warunkom wypału. Warto w tym miejscu zasugerować analizę ceramicznych odpadów produkcyjnych właśnie pod tym kątem.

Liczne odpady produkcyjne stworzyły złudny efekt dużych rozmiarów produkcji, który znalazł się u podstaw interpretacji osad nadrabskich jako dużych centrów wytwórczości ceramiki wykonanej na kole (Kaczanowski, Kozłowski 1998, s. 306-307). Przeciwko takiemu wnioskowi świadczy zarówno ograniczony dostęp do dobrej jakości surowców w rejonie wymienionych stanowisk, jak i problemy z prawidłowym funkcjonowaniem pieców garncarskich (Dobrzańska 2015).

W odległości około $17 \mathrm{~km}$ na zachód od stanowisk odkrytych nad Rabą rozciąga się strefa osadnictwa nad Wisłą, gdzie niemal we wszystkich badanych archeologicznie osadach odkryto pozostałości wytwórczości garncarskiej. Piece garncarskie budowane były w strefach produkcyjnych osad, wgłębione w stok lessowej terasy lewego brzegu Wisły (w terminologii geograficznej na jej krawędzi), np. w Igołomi, woj. małopolskie stan. 1, Zofipolu, woj. małopolskie, stan. 1, Krakowie-Pleszowie, stan. 17-20. Był to obszar dobrze odwodniony, z regularną cyrkulacją powietrza (Dobrzańska 2000, s. 46, 47, ryc. 11). Wytwarzana tam ceramika gładka, szara, charakteryzowała się znaczną twardością czerepu i powierzchnią wyświecaną. W odróżnieniu od stanowiska w Bessowie, gdzie w rejonie pracowni i jednego pieca garncarskiego odkryto 22000 fragmentów ceramiki, spośród których aż 47\% nosi ślady nieintencjonalnego wypału redukcyjnego, w Igołomi kompleks czterech pieców, skupionych w pobliżu chaty garncarza (obiekt 1/52), związanej także z wytwórczością naczyń, dostarczył jedynie około 6000 odpadów produkcyjnych (Dobrzańska 1990a, s. 59-75; taż 1990b, s. 24-26). Wśród nich najczęściej spotykane noszą ślady deformacji, będącej efektem oddziaływania zbyt wysokiej temperatury. Wśród ceramiki szarej, tylko około $7 \%$ stanowią odpady o cechach wypału utleniającego, z przypadkowym dopływem tlenu. Mają barwę beżową, szaro-beżową, pomarańczową.

Pojedyncze piece garncarskie odkryto także na równinie zalewowej Wisły, np. w Krakowie-Przewozie, stan. 2, czy też na stan. 6 w Krakowie Wyciążu (Dobrzańska 2013, s. 107). Wśród odpadów produkcyjnych, pochodzących z tych stanowisk, fragmenty naczyń o ścieralnych powierzchniach występują obok ceramiki o powierzchniach wyświecanych (Dobrzańska, Kalicki 2018, s. 120, 137, przypis 1). Główną przyczyną jej złej jakości mógł być trudny dostęp garncarzy do surowców, w porównaniu z wytwórcami pracującymi w osadach na terasie lessowej. Ci ostatni mogli stosunkowo łatwo pozyskiwać zróżnicowane materiały, należące do holoceńskich aluwiów rzecznych. Było to możliwe dzięki znacznemu pogłębieniu koryt bezimiennych dopływów Wisły, u podnóża terasy lessowej, co nastąpiło w wyniku obniżenia poziomu koryta tej rzeki, około przełomu er. Potok płynący poniżej osady w Zofipolu rozciął ilaste osady pozakorytowe zalegające w basenie powodziowym, sięgając do stropu iłów mioceńskich. Odsłonięte, zróżnicowane aluwia (mady), podobnie jak wymienione iły (obecne w badanej ceramice), mogły być bez więk- 
of potters dealing with the changeable air circulation patterns in the Raba floodplain that were the cause of losses in pottery production. The high water level in the area during frequent short flooding events, resulting from climate deterioration in the Roman period, must have been an additional impediment (Dobrzańska, Kalicki [2011] 2013). The kiln structure is an apparent adaptation to the unfavourable conditions presented by the local geographical environment. One should commend the potters' building skills with regard to the kilns and their extensive knowledge of the principles of operation as well as technological experience.

The difficulties in production, resulting from unfavourable environmental factors as well as inadequate raw material, could have been the reason for the considerable quantities of production waste found in the workshops on the Raba river, including the $47 \%$ of rejects reflecting unintentional oxidation during firing. It would be worthwhile to analyse the pottery production waste in this direction.

The abundant waste gave an impression of massive production, which in turn led to the interpretation of the Raba settlements as large centers of wheel-made pottery production (Kaczanowski, Kozłowski 1998, pp. 306-307). However, restricted access to quality clay in the immediate vicinity of these sites, as well as evident problems with the proper functioning of the kilns, would question this idea (Dobrzańska 2015).

About $17 \mathrm{~km}$ west of the Raba cluster of sites, in the settlement zone on the Vistula, almost all of the sites tested archaeologically brought evidence of pottery production. Pottery kilns were set up in the production zones of these settlements, dug into the loess slope of the left-bank river terrace (at the edge to use geographical terminology), e.g., Igołomia, site 1, Zofipole, site 1, and Kraków-Pleszów, sites 17-20, all Małopolskie voivodeship. This was a well drained area with regular air circulation (Dobrzańska 2000, pp. 46, 47, Fig. 11). The pottery made there, a smooth grey ware, was characterized by considerable hardness of the body and burnished surface. Unlike the Bessów site, where in the workshop and one kiln area discovered were 22,000 pottery sherds, of which as much as $47 \%$ bore traces of unintentional reductive firing, the four kilns from Igołomia, which were clustered around a potter's hut (feature 1/52), also connected with vessel production, yielded only approximately 6000 pieces qualified as production waste (Dobrzańska 1990a, pp. 59-75; eadem 1990b, pp. 24-26). Deformation due to excessively high temperature was the most frequently encountered flaw. Only about $7 \%$ of the grey ware waste demonstrates oxidation firing as a result of accidental oxygen flow, the coloring of the bodies ranging from beige and grey-beige to orange.

Single pottery kilns were discovered also in the floodplain of the Vistula, at Kraków-Przewóz, site 2, or Kraków Wyciąże, site 6, for example (Dobrzańska 2013, p. 107). The production waste from these sites includes sherds with abradable surfaces next to the ones with burnished bodies (Dobrzańska, Kalicki 2018, pp. 120, 137, note 1). The main reason of the poor quality in this case was encumbered access to raw materials as compared to producers located on the loess terraces, who had relative ease in procuring a variety of material representing Holocene river alluvia. It was possible thanks to a considerable deepening of the beds of nameless tributaries of the Vistula at the foot of the loess terrace, which occurred as a result of the lowering of the Vistula bed around the turn of the eras.

The stream flowing beneath the Zofipole settlement cut through the silty overbank sediments, in the backswamp, reaching the top of the Miocene clays. The differentiated Holocene river alluvia that were thus exposed could now be easily exploited, like the said Miocene clays (present in the tested pottery), in vessel production (Dobrzańska, Kalicki 2018, pp. 123, 137). The potters working in the floodplain, especially at Kraków-Przewóz, site 2, which was located close to the Vistula river bed, had neither the same opportunities nor choice of raw material. Geomorphological studies in the floodplain have demonstrated that sediments accumulated near the river bed but outside it were characterized by a coarser fraction (raw material of poorer 
szego wysiłku pobierane do produkcji naczyń (Dobrzańska, Kalicki 2018, s. 123, 137). Takich możliwości i takiego wyboru nie mieli garncarze pracujący na równinie zalewowej, zwłaszcza w Krakowie-Przewozie, stan. 2, osadzie położonej blisko koryta Wisły. Rezultaty badań geomorfologicznych przeprowadzonych na równinie zalewowej, wskazują, że osady pozakorytowe (mady), o grubszej frakcji (gorszej jakości surowiec) akumulowane były blisko koryta, a bardziej ilaste, o coraz drobniejszej frakcji, osadzane były w miarę oddalania się od Wisły (Kalicki 1991; 2000), a więc w kierunku podnóża terasy lessowej. Dodatkowym utrudnieniem dla pracy pieców były wahania poziomu wód gruntowych, podobnie jak w rejonie nadrabskim.

Wyniki badań odpadów produkcyjnych z Bessowa, stan. 3, nie mogą stanowić podstawy do charakterystyki stosowanego tam procesu technologicznego, natomiast dokumentują one problemy, z jakimi borykali się pracujący tam garncarze. Nie ma racjonalnych przesłanek, aby uznać, że do wypału ceramiki z masy garncarskiej o dużej zawartości kwarcu stosowano specjalną technologię, w której istotną rolę odgrywała wysoka temperatura. Przedstawione wyżej rozważania, w których uwzględniono wyniki studiów paleogeograficznych, prowadzą do wniosku, że ścieralność ceramiki nie może być interpretowana jako wskaźnik o charakterze kulturowym, ale jest ona wynikiem użycia gorszej jakości materiału, przy ograniczonym dostępie do dobrej jakości surowców.

Ceramika o takich cechach odkrywana jest w różnych, nieraz odległych od siebie, rejonach europejskiego Barbaricum. Ponieważ efekt ścieralności nie jest intencjonalny, zatem nie można go łączyć z jakąś szczególną technologią, przypisywaną określonej ludności czy też obcym tradycjom kulturowym, jak to ma miejsce w przypadku stanowisk w Pakoszówce. Omawiany tu efekt jest niezależny od sfery kulturowej. 
quality), whereas the finer material with higher clay content tended to be more abundant further away from the Vistula (Kalicki 1991; 2000), that is, increasing in quantity in the general direction of the foot of the loess terrace. The groundwater level changes were an additional impediment, just like in the Raba region.

The production waste from Bessów, site 3, is therefore not suitable for technological studies of the production process employed there, but it highlights the problems that local potters encountered in their work. There are no rational premises for assuming a special technology based on high firing temperatures for the firing of pottery made from a fabric containing large quantities of quartz. The discussion presented above, taking into account the results of paleogeographical studies, leads to the conclusion that pottery abradability cannot be interpreted as a cultural indicator. It is the result of the use of raw material of poorer quality in a situation of restricted access to better-quality material.

Pottery demonstrating abradable surfaces is discovered in sometimes very distant regions of the European Barbaricum, but since the abradability effect was not intentional, it cannot be linked to any special technology ascribed to a specific population or to a foreign cultural tradition as was the case with regard to the finds from the Pakoszówka sites. The abradability effect that has been discussed here is independent of the cultural sphere. 


\section{WYKAZ CYTOWANEJ LITERATURY}

\section{BIBLIOGRAPHY OF WORKS CITED}

A r nold D. 1985, Ceramic theory and cultural process, Cambridge.

Bulas J., Mazurek M., Okońska M., Poradyło W. 2019, Wielokulturowe stanowisko 59-60 w Sanoku w świetle badań wykopaliskowych 2017-2018, Sum.: Multicultural site 59-60 in Sanok in the light of excavations in the years 2017-2018, „Raport”, 14 , pp. 55-81.

Daszkiewicz M., Okońska M., Bobryk E. 2018, Defective technology or alteration effect? The case of Pakoszówka-Bessów type pottery (Bessów, south Poland), [in:] Archäometrie und Denkmalpflege, L. Glaser ed., Hamburg, pp. 50-53.

D o b r z a ń ska H. 1990a, Osada z późnego okresu rzymskiego w Igołomi, woj. krakowskie, Część I, Materiały, Sum.: The Late Roman settlement at Igołomia, Cracow province, Part I, Materials, Wrocław-Warszawa-Kraków-Gdańsk.

D o b r z án ska H. 1990b, Osada z późnego okresu rzymskiego w Igołomi, woj. krakowskie, Część II, Sum.: The Late Roman settlement at Igołomia, Cracow Provence, Part II, Kraków.

D o b r z a ń s k a H. 2000, Ośrodek produkcji ceramiki „siwej” z okresu rzymskiego w Zofipolu, Zusamm.: Das Produktionszentrum der kaiserzeitlichen „grauen” Keramik in Zofipole, [in:] 150 lat Muzeum Archeologicznego w Krakowie, J. Rydzewski ed., Kraków, pp. 37-68.

D o b r z a ń s k a H. 2013, Les ateliers de potiers de la période romaine en Pologne - projet "La vallée de la Vistule", [in:] Numéro spécial des Annales de l'Académie Polonaise des Sciences, Centre Scientifique à Paris, 8, Archéologie, B.S. Szmoniewski ed., Varsovie-Paris, pp. 79-116.

D o b r z án s k a H. 2015, Ośrodki wytwórczości ceramiki kultury przeworskiej w dolinie Wisty, na wschód od Krakowa oraz nad Raba, w kontekście geograficznym i kulturowym, Sum.: Pottery production centers of the Przeworsk culture in the Vistula valley to the east of Cracow and on the Raba River, in the geographic and cultural context, [in:] Barbari superiores et Inferiores. Archeologia barbarzyńców 2014. Proces integracji środkowoeuropejskiego Barbaricum. Polska - Czechy - Morawy - Słowacja, L. Tyszler, E. Droberjar eds, Łódź-Wieluń, pp. 389-407.

Dobrzańska H., Kalicki T. [2011] 2013, Climate and man in the Kraków region ( $3^{\text {rd }}$ century $B C-7^{\text {th }}$ century AD), „Archaeologia Polona”, 49, pp. 135-151.

Dobrzańska H., Kalicki T. 2015, Morphology and land use of floodplains in the western part of Sandomierz Basin (southern Poland, Central Europe) in the Roman period, "Quaternary International”, 370, pp. 100-112.

D obrzańska H., Kalicki T. 2018, Osadnictwo ludności kultury przeworskiej na równinach zalewowych $w$ zachodniej części Kotliny Sandomierskiej, Sum.: Settlement of Przeworsk Culture in the flood plains of the western Sandomierz Basin, „Archeologia Polski”, 63, pp. 119-143.

Dobrzańska H., Kielski A., Wodnicka K. 2003, Ceramika archeologiczna „ścieralna”, [in:] Postępy technologii ceramiki, szkła i budowlanych materiałów wiążących. Z. Pędzich i K. Haberko eds, „Prace Komisji Nauk Ceramicznych, Polski Biuletyn Ceramiczny - Ceramika”, 80, Kraków, pp. 565-572.

D obrzańska H., Ki elski A., Wodnicka K. 2004, Ścieralnośćceramiki „siwej” zjawisko kulturowe czy technologiczne?, Sum.: Softness of the grey pottery - cultural or technological phenomenon, [in:] Okres lateński i rzymski w Karpatach polskich. Materiały $z$ konferencji, J. Gancarski ed., Krosno, pp. 679-690. 
Dobrzańska H., Kielski A., Wodnicka K. 2008, Firing conditions and properties of the Roman period grey ceramics, „Archaeologia Polona”, 46, pp. 241-250.

Dušek S., Hohmann H., Mülle r W., Schmidt W. 1986, Haarhausen I. Rekonstruktion eines Töpferofens und des Brennverfahrens, „Weimarer Monographien zur Ur- und Frühgeschichte", 16, Weimar.

D z ięg i elewska M., D z i ęg i elew ski K. 2015, Glinianki użytkowane przez ludność kultury przeworskiej $w$ młodszym okresie wpływów rzymskich $w$ Modlnicy, Sum.: Clay pits used by the Przeworsk culture population in the Younger Roman Period in Modnica, [in:] Modlnica, stan. 5. Od późnej epoki brązu po czasy średniowiecza, M. Dzięgielewska, K. Dzięgielewski, A. Sztyber eds, „Via Archaeologica. Źródła z badań wykopaliskowych na trasie autostrady A4 w Małopolsce”, Kraków, pp. 263-307.

G ę b i c a P. 1995, Ewolucja doliny Wisty pomiędzy Nowym Brzeskiem a Opatowcem w vistulianie i holocenie, Sum.: Evolution of the Vistula River Valley between Nowe Brzesko and Opatowiec in the Vistulian and Holocene, „Dokumentacja Geograficzna”, 2, Warszawa.

Goerlich E., Muszyński L., Rodak J. 2005, Eksperymentalny wypał naczyń glinianych i jego efekty, [in:] Eksperymentálna archeológia a popularizácia archeologického bádania $v$ múzejnej a školskej praxi, M. Kotorová-Jenčová ed., Hanušovce nad Toplou, pp. 63-71.

Ka c z a n o w ski P., Ko zło w ski J.K. 1998, Najdawniejsze dzieje ziem polskich. Wielka Historia Polski, 1, Kraków.

Ka l i c k i T. 1991, The evolution of the Vistula River Valley between Cracow and Niepołomice in late Vistulian and Holocene times, [in:] Evolution of the Vistula River Valley during the last 15000 years, Part IV, „Geographical Studies, Special Issue”, 6, pp. 11-37.

Ka li c k i T. 2000, Grain size of the overbank deposits as carriers of paleogeographical information, „Quaternary International”, 72, pp. 107-114.

Kordecki J. O koń ski J. 1999, Mikroregion osadniczy na prawobrzeżu dolnego biegu Raby, Zusamm.: Eine Siedlungskammer im unteren Flusses Raba, [in:] Na granicach antycznego świata. Sytuacja kulturowa w południowo-wschodniej Polsce i regionach sąsiednich $w$ młodszym okresie przedrzymskim i okresie rzymskim, S. Czopek, A. Kokowski eds., Rzeszów, pp. 181-215.

M a d y d a - L e g u t k o R. 1996, Zróżnicowanie kulturowe polskiej strefy beskidzkiej w okresie lateńskim i rzymskim, Zusamm.: Kulturelle Differenzierung der polnischen Beskidenzone in der La Tène- und der Römischen Kaiserzeit, Rozprawy habilitacyjne, 304/1, Kraków.

M a d y d a - L e g u t k o R. 2010, Zróżnicowanie regionalne ceramiki wykonanej na kole garncarskim na przykładzie materiałów zabytkowych pochodzacych z polskich Karpat, [in:] Ceramika rzemieślnicza jako źródło do badań nad zróżnicowaniem garncarstwa kultury przeworskiej, H. Machajewski, B. Jurkiewicz eds., Pułtusk, pp. 17-34.

Madyda-Legutko R., Pohorska-Kleja E., Rodzińska-Nowak J. 2004, Warsztat garncarski $z$ Sanoka, stan. 54, na tle materiałów ceramicznych z terenu górnego dorzecza Sanu, Zusamm.: Eine Töpferwerkstatt von Sanok, FSt. 54, vor dem Hintergrund anderer Keramikfunde aus dem oberen Sangebiet, [in:] Okres lateński i rzymski w Karpatach polskich. Materiały z konferencji, J. Gancarski ed., Krosno, pp. 691-707.

O k o ń s k a M. [ 2017] 2018, A case-study of the so-called "pottery depot" from Bessów, site 3, commune Bochnia, Małopolska province. Archaeological material and functional re-interpretation, „Recherches Archèologiques”, NS 9, pp. 349-377.

Okońska M., Daszkiewicz M., B obryk E. 2018, Ceramic technology used in the production of easily abradable pottery (Pakoszówka-Bessów type) from Bessów site 3 in light of archaeometric analysis, „Acta Archaeologica Carpathica”, 53, pp. 97-128. 
O k o ń s ki J. [ 1999] 2000, Osada na stanowisku w Bessowie, gm. Bochnia, na tle nadrabskiego mikroregionu osadniczego, „Acta Archaeologica Carpathica”, 35, pp. 113-167.

S i c iń s k i W. 2000, Osada kultury przeworskiej z poźnego okresu rzymskiego, [in:] Badania archeologiczne na terenie odkrywki „Szczerców” Kopalni Węgla Brunatnego „Bełchatów” S.A., 1, R. Grygiel ed., Łódź, pp. 52-83. 